\title{
Dental education and proportion of inhabitants by Dentist in Angola
}

\author{
Educação em odontologia e proporção de habitantes por Cirurgião-Dentista em Angola \\ Educación en odontología y proporción de habitantes por Odontólogo en Angola
}

Received: 03/28/2021 | Reviewed: 04/06/2021 | Accept: 04/09/2021 | Published: 04/20/2021

\author{
Suzely Adas Saliba Moimaz \\ ORCID: https://orcid.org/0000-0002-4949-529X \\ São Paulo State University, Brazil \\ E-mail: suzely.moimaz@unesp.br \\ Marcial António Simão Songa \\ ORCID: https://orcid.org/0000-0003-0071-062X \\ São Paulo State University, Brazil \\ E-mail: massonga06@gmail.com \\ Nemre Adas Saliba \\ ORCID: https://orcid.org/0000-0001-9608-1631 \\ São Paulo State University, Brazil \\ E-mail: nemre.saliba@unesp.br \\ Tânia Adas Saliba \\ ORCID: https://orcid.org/0000-0003-1327-2913 \\ São Paulo State University, Brazil \\ E-mail: tania.saliba@unesp.br
}

\begin{abstract}
The objective was to verify the proportion of dentists in relation to the Angolan population, to undergraduate and graduate courses in dentistry, and to analyze the pedagogical projects of the existing courses. This is a descriptive, exploratory and documentary study that analyzed data on the population and the number of dentists in Angola, obtained through information from the National Statistics Institute and the Order of Doctors of Angola. An application for cell phones called "Qualificar", made available by the Angolan government, was used to collect information about the existing courses. The websites of the Ministry of Higher Education, Science, Technology and Innovation; National Institute for Evaluation, Accreditation and Recognition of Higher Education Studies in Angola; and the National Press were consulted to collect data related to higher education in Angola. Information on pedagogical projects was obtained directly from Higher Education Institutions (HEIs). Angola has 701 dentists registered for a population of $30,175,553$ inhabitants, that is, a proportion of $1 / 43,460$. Among the eighty existing HEIs, only ten were authorized by the government to offer undergraduate courses in dentistry: six were located in the country's capital and four were distributed in other provinces, with workload varying from 4,688 to 5,536 hours. It was concluded that of the seven academic regions in the country, 4 do not have courses in dentistry; the number of dentists is not compatible with the population of Angola; no HEI offered postgraduate courses in dentistry and there is no standardization of pedagogical projects among the existing undergraduate courses.
\end{abstract}

Keywords: Higher education institutions; Dentistry; Education, Graduate; Angola.

\section{Resumo}

Objetivou-se verificar a proporção de cirurgiões-dentistas em relação à população angolana, aos cursos de graduação e pós-graduação em odontologia, e analisar os projetos pedagógicos dos cursos existentes. Trata-se de um estudo descritivo, exploratório e documental que analisou dados da população e do número de cirurgiões-dentistas em Angola, obtidos por meio de informações do Instituto Nacional de Estatística e da Ordem dos Médicos de Angola. Um aplicativo para telefones celulares chamado "Qualificar", disponibilizado pelo governo de Angola, foi usado para coletar informações sobre os cursos existentes. As páginas eletrônicas do Ministério da Educação Superior, Ciência, Tecnologia e Inovação; Instituto Nacional de Avaliação, Acreditação e Reconhecimento de Estudos do Ensino Superior em Angola; e da Imprensa Nacional foram consultados para a coleta de dados relacionados ao ensino superior em Angola. As informações sobre os projetos pedagógicos foram obtidas diretamente nas Instituições de Ensino Superior (IES). Angola tem 701 cirurgiões-dentistas cadastrados para uma população de 30.175 .553 habitantes, ou seja, uma proporção de 1/43.460. Entre as oitenta IES existentes, apenas dez foram autorizadas pelo governo a oferecer cursos de graduação em odontologia: seis estavam localizadas na capital do país e quatro estavam distribuídas em outras províncias, com carga horária variando de 4.688 a 5.536 horas. Concluiu-se que das sete regiões acadêmicas existentes no país, 4 não possuem cursos de odontologia; o número de cirurgiões-dentistas não é compatível com a população de Angola; nenhuma IES ofereceu cursos de pós-graduação em odontologia e não há padronização de projetos pedagógicos entre os cursos de graduação existentes.

Palavras-chave: Instituições de ensino superior; Odontologia; Educação de pós-graduação; Angola. 


\section{Resumen}

El objetivo fue verificar la proporción de cirujanos dentistas en relación con la población angoleña, cursos de pregrado y posgrado en odontología, y analizar proyectos pedagógicos de los cursos existentes. Se trata de un estudio descriptivo, exploratorio y documental que analizó datos sobre la población y el número de dentistas en Angola, obtenidos a través de información del Instituto Nacional de Estadística y la Orden de Doctores de Angola. Se utilizó una aplicación para teléfonos móviles denominada "Qualificar”, puesta a disposición por el gobierno angoleño, para recopilar información sobre los cursos existentes. Las páginas web del Ministerio de Educación Superior, Ciencia, Tecnología e Innovación; Instituto Nacional de Evaluación, Acreditación y Reconocimiento de Estudios de Educación Superior en Angola; se consultó la Prensa Nacional para recopilar datos relacionados con la educación superior en Angola. La información sobre proyectos pedagógicos se obtuvo directamente de Instituciones de Educación Superior (IES). Angola tiene registrados 701 dentistas para una población de 30.175 .553 habitantes, es decir, una proporción de 1/43.460. Se concluyó que de las siete regiones académicas del país, 4 no cuentan con cursos de odontología; el número de cirujanos dentistas no es compatible con la población de Angola; ninguna IES ofreció cursos de posgrado en odontología y no existe una estandarización de proyectos pedagógicos entre los cursos de pregrado existentes.

Palabras clave: Instituciones de enseñanza superior; Odontología; Educación de postgrado; Angola.

\section{Introduction}

The scarcity of Human Resources for Health (HRH) is a global concern, which is most acute in sub-Saharan Africa, where the magnitude of the problem has already reached critical levels. According to the World Health Organization (WHO), Thirty-six of the fifty-seven countries facing an HRH crisis are African. Three of the Portuguese-speaking African Countries (Mozambique, Angola, and Guinea Bissau) are among the most affected (Dussault, Fronteira, \& World Health Organization, 2010).

Developing countries are being encouraged by WHO and the World Federation of Dentistry, together with dental care organizations, and volunteers, to incorporate the basic oral hygiene package as a guiding framework for providing oral health services (Karim, Mascarenhas, \& Dharamsi, 2008). In South Africa, undergraduate courses are taught through collaborations between the South African Department of Health and each university, which is akin to an academic-service partnership. South African universities rely on government grants to fund their operating costs. Grants are based on the production of original research publications and the number of accredited graduates (Grossman \& Naidoo, 2012). A good health-care system depends on the abilities of the human resources that a part of the system. Thus, health-care systems are dependent on infrastructure, material resources, and on the availability of qualified medical personnel (Parkash et al., 2006).

The prominent features of oral healthcare in Africa include a scarcity of employees in the oral health field, imbalances between medical personnel and the needs of the population, and the low priority afforded to oral health care, owing to the presence of various general health problems and massive development needs (Thorpe, 2006). Developing countries that decide to expand their health-care system by increasing the number of educational institutions in the areas requiring them face a shortage of trained local professionals. Usually, healthcare professionals receive advanced training in foreign countries. However, few return to their native countries after completion (Peters et al., 2013).

Angola is located on the west coast of Africa, with a projected population of 30,175,553 inhabitants for the year 2019, with an area of $1,247,000 \mathrm{~km} 2$. Portuguese is the official language and several dialects are spoken. The life expectancy is 60.2 years, and the average age is 20.6 years. Unemployment reaches $29.0 \%$ of the active population (Instituto Nacional de Estatística de Angola, 2019). Higher education was established in Angola in 1962, with the creation of the General University Studies of Angola. With the proclamation of Angola's political independence in 1975, the University of Angola was established in 1976, which is the only national institute of higher education. In 1985, the University of Angola was renamed Agostinho Neto University, which until 2009 was the only state-run institution providing higher education in the country (Carvalho, 2012).

Following the proclamation of independence, the country was riven with the political, economic, and social disturbances, marking the beginning of a civil war that ended after 27 years. The escalating conflict destroyed academic 
infrastructure, especially in the rural areas, which was further impacted by teacher absenteeism, low school attendance, and limitations on the state budget to cope with the investment needed for human resources and infrastructure development (Liberato, 2014). In 2001, the government identified the following principal issues afflicting higher education in Angola: the demand for higher education was greater than the supply, and the demand was likely to increase, and higher educational institutions (HEI) were mainly located in the province of Luanda (the capital of the country), the training programs offered were not always suited to the economic and social needs and the labor market, the teaching programs often constituted few practical and research components, and the availability of financial resources was highly variable, uncertain, and generally insufficient (Governo da República de Angola, 2001). After identifying the problems, the HEIs in Luanda were deconcentrated and 7 academic regions were created in the country. These regions would provide the population with the opportunity to pursue higher education in their city or in another city near their own in Angola. Difficulties persisted, since the availability of HEIs does not meet the demand and the high poverty rate in the country, which is a hindrance in this regard, still exists (Governo da República de Angola, 2009).

The first decrees that endorsed the undergraduate courses in dentistry were approved in 2008. The Jean Piaget University of Angola and Private University of Angola were established by other decrees initiated in 2012, and the following years (Governo da República de Angola, 2008). Was approved by Presidential Decree Number 109/19, passed on April 2019, the "researcher's career status", that given the need for establishing standards that contribute to the enhancement of the dignity of scientific researchers, enabling their development, motivation, retention and employment to appropriate scientific positions and their integration into national and international scientific research teams (Governo da República de Angola, 2019). This in turn prompted technological development and innovation in the country. Career opportunities for dental researchers need to be created and enhanced, because the number of dental researches published on Angola is insignificant, whether by national or foreign researchers, considering that the number of dentists enrolled in the Order of Doctors is still small.

Studies published in the scientific literature related to higher education in Angola have focused on other fields, and studies on dental education are scarce. There is a need for detailed health-care related studies, focusing on dental education, which could improve the appreciation and adequacy of the curricula for undergraduate dentistry courses, and employ qualified staff to equip students to face the challenges posed by the profession. The objective of this study was to analyze the proportion of dentists in relation to the population of Angola, the undergraduate and postgraduate courses in dentistry in the academic regions, and to analyze the pedagogical projects of the courses existing in 2019.

\section{Methodology}

This is descriptive, exploratory and documentary study on the projection of the population of Angola from the National Institute of Statistics (INE) and the number of dentists from the website of the Order of Doctors of Angola. An application called "Qualificar," which can be used with cellular phones with iOS and Android operating systems, was made available by the government of Angola, to gain information regarding the existing courses in the country. The websites of the Ministry of Higher Education, Science, Technology and Innovation; National Institute for Evaluation, Angolan Accreditation and Recognition of Higher Education Studies (INAREES), and the National Press were also consulted to collect data related to higher education in Angola in 2019. Information on the pedagogical projects was obtained directly from the HEIs.

After considering the distance between the different provinces and the limited resources, the HEIs were researched by the official webpages of the Ministry of Higher Education, Science, Technology and Innovation, the official page of the National Press, for the decrees authorizing the creation of undergraduate dentistry courses, published in Republic Diary. After the consultation on the electronic pages, requests were sent to the emails published on the official pages of some HEIs, specifically in the academic services, to obtain the curricular plan of the undergraduate course in dentistry. Another attempt to 
obtain the data was made by sending emails to the HEI directors who had electronic contacts on the HEI official pages. Data were also collected in person at the HEI. From these steps, answers from six HEIs were obtained, of which three from personal contact (Jean Piaget University of Angola, Benguela Higher Polytechnic Institute and Kalandula Higher Polytechnic Institute), two replies from the official pages (Angolan Higher International Institute), one reply by email (Caála Higher Polytechnic Institute). Of the remaining four HEIs, two have not answered (Private University of Angola and Dawn Youth Polytechnic Higher Institute) and two are not teaching (Lubango Evangelical Higher Polytechnic Institute and Uíge Private Polytechnic Higher Institute). The educational schemes were analyzed considering the following variables: enrollment and entry of new students regime, annual vacancies offered, modalities, total course workload, course duration in years, number of teachers hired at HEI, curricular units taught, duration and workload of the curricular units offered.

The proportion of inhabitants per dentist was calculated by the ratio between the absolute number of inhabitants of Angola, obtained through data from the website of National Institute of Statistics (INE), and the number of professionals registered in the website of Order of Doctors of Angola.

Data were presented in tables and a geographical representation of the location of the courses.

\section{Results}

There are 701 dentists for a population of 30,175,553, individuals in Angola, i.e., a proportion of 1/43,046. Angola is divided into seven academic regions, as follows: I - Luanda and Bengo (based in Luanda); II - Benguela and Kwanza Sul (based in Benguela); III - Cabinda and Zaire (based in Cabinda); IV - Lunda-Norte, Lunda-Sul and Malange (based in LundaNorte); V - Huambo, Bié and Moxico (based in Huambo); VI - Huila, Cunene, Cuando-Cubango and Namibe (based in Huila); VII - Kwanza Norte and Uíge (based in Uige). It is noted that only academic regions I, II and V have HEI with dentistry courses (Figure 1).

Figure 1. Geographic distribution of dentistry courses in Angola, 2019.

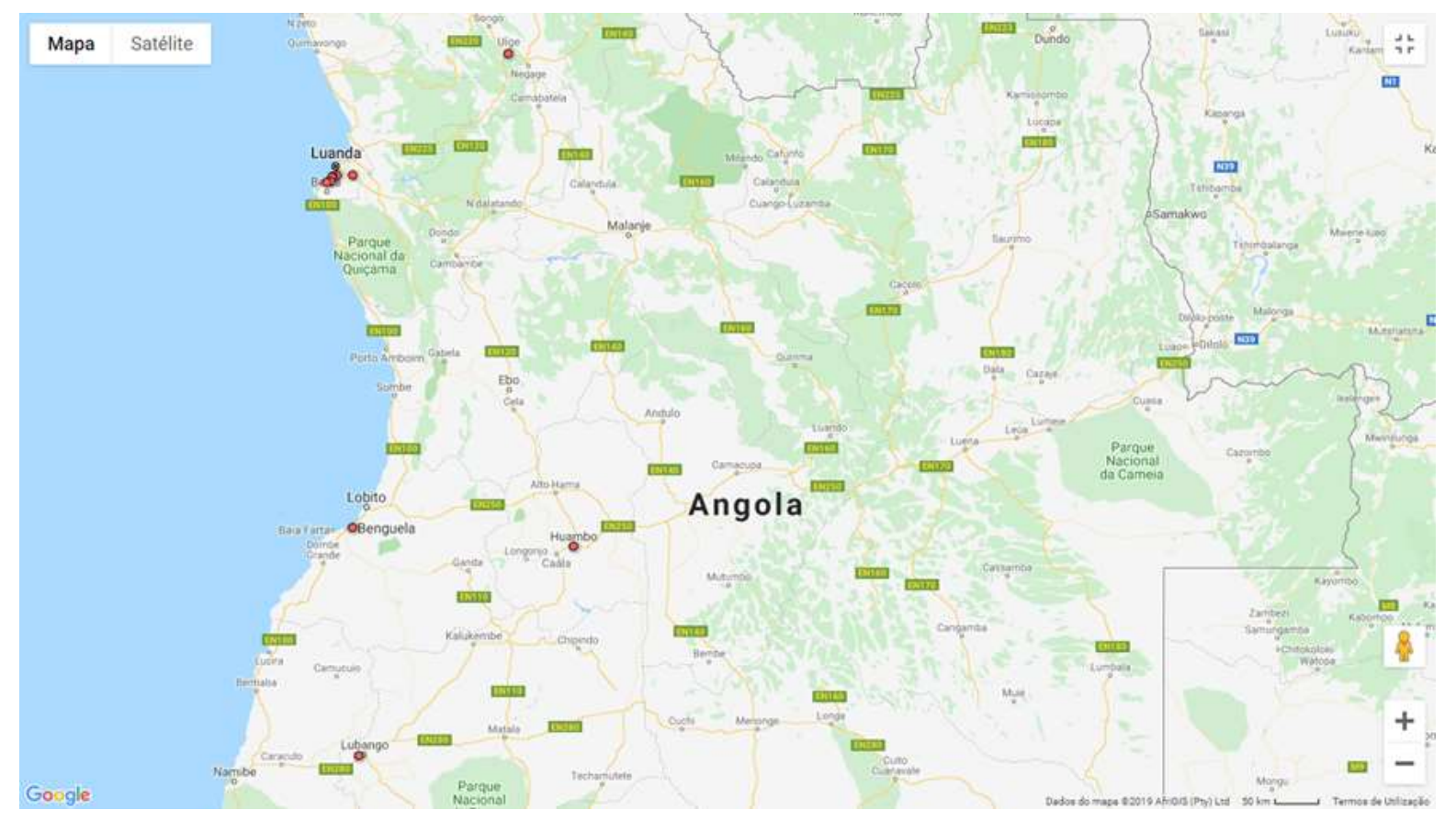

The red circles indicate the location of the higher educational institutions with dentistry courses. Source: Authors/ Map extracted from Google maps. 
Of the eighty HEIs in the country, only ten private HEIs have undergraduate dentistry courses: six are located in the country's capital and four are divided between the provinces of Benguela, Huambo, Huila, and Uíge (Table 1).

Table 1. Higher Education Institutions in Angola offering undergraduate dentistry courses, 2019.

\begin{tabular}{|c|c|c|c|c|c|}
\hline Higher Educational Institution (HEI) & $\begin{array}{l}\text { Acronym } \\
\text { HEI }\end{array}$ & Province & Nature & Executive Decree & Course \\
\hline Universidade de Belas & UNIBELAS & Luanda & Private & $\begin{array}{llll}171 / 11 & \text { de } & 10 & \text { of } \\
\text { October } & & & \end{array}$ & Dentistry \\
\hline Universidade Jean Piaget de Angola & UNIPIAGET & Luanda & Private & $76 / 08$ de 11 of Jun & Dentistry \\
\hline Universidade Privada de Angola & UPRA & Luanda & Private & $\begin{array}{llll}178 / 08 & \text { de } & 19 & \text { Of } \\
\text { August } & & & \end{array}$ & Dentistry \\
\hline $\begin{array}{l}\text { Instituto Superior Politécnico Alvorecer da } \\
\text { Juventude }\end{array}$ & ISPAJ & Luanda & Private & $\begin{array}{llll}426 / 12 & \text { de } & 17 & \text { de } \\
\text { October } & & & \end{array}$ & Dentistry \\
\hline Instituto Superior Politécnico de Benguela & ISPB & Benguela & Private & $16 / 12$ de 10 de January & Dentistry \\
\hline $\begin{array}{l}\text { Instituto Superior Politécnico Internacional de } \\
\text { Angola }\end{array}$ & ISIA & Luanda & Private & 190/16 de 01 de April & Dentistry \\
\hline Instituto Superior Politécnico Kalandula & ISPEKA & Luanda & Private & $\begin{array}{l}434 / 12 \text { de } 25 \text { of } \\
\text { October }\end{array}$ & Dentistry \\
\hline Instituto Superior Politécnico da Caála & ISPC & Huambo & Private & Awaiting publication & Dentistry \\
\hline $\begin{array}{l}\text { Instituto Superior Politécnico Evangélico do } \\
\text { Lubango }\end{array}$ & ISPEL & Huila & Private & Awaiting publication & Dentistry \\
\hline Instituto Superior Politécnico Privado do Uíge & ISPPU & Uíge & Private & Awaiting publication & Dentistry \\
\hline
\end{tabular}

Source: Authors.

Of the ten HEIs authorized to offer undergraduate dentistry courses, only eight are currently offering courses (Table 2). No public HEI has an undergraduate dentistry course and no HEI in Angola offers postgraduate dentistry courses. Some public hospitals in Angola offer specialization courses in maxillofacial surgery. As such, it is the only specialty and opportunity available to a dental graduate in Angola, if he/she wishes to continue your educational training within the country.

First decrees authorizing the provision of undergraduate dentistry courses in Angola, were signed and published fifteen years ago. The study allowed the collection of data on the academic projects of six HEIs, and verified the number of curricular units that available at each HEI and the HEIs that did not provide such information and others that gave insufficient information. 
Table 2. Curriculum of Undergraduate Dentistry Course in Angola, 2019.

\begin{tabular}{cccccccccc}
\hline HEI & Regime & Entry & $\begin{array}{c}\text { Annual } \\
\text { Vacancies }\end{array}$ & Modality & Workload & Duration & Teachers & \multicolumn{2}{c}{ Curricular units } \\
& \multicolumn{2}{c}{} & & & & & Annual & Semiannual \\
\hline UNIBELAS & Serial & Annual & - & Disciplinary & - & 5 years & - & - & - \\
UNIPIAJET & Serial & Annual & - & Disciplinary & - & 5 years & - & 6 & 53 \\
UPRA & Serial & Annual & - & Disciplinary & - & 5 years & - & 0 & 81 \\
ISPAJ & Serial & Annual & - & Disciplinary & - & 4 years & - & - & - \\
ISPB & Serial & Annual & 45 students & Disciplinary & $5.370 \mathrm{~h}$ & 6 years & 38 & 24 & 21 \\
ISIA & Serial & Annual & - & Disciplinary & $4.688 \mathrm{~h}$ & 5 years & - & 0 & 68 \\
ISPEKA & Serial & Annual & - & Disciplinary & - & 5 years & - & 2 & 67 \\
ISPC & Serial & Annual & - & Disciplinary & $5.536 \mathrm{~h}$ & 5 years & - & 1 & 69 \\
ISPEL & - & - & - & - & - & - & - & - & - \\
ISPPU & - & - & - & - & - & - & - & - & - \\
\hline
\end{tabular}

Source: Authors.

Characterization of the Polytechnic Higher Institute of Benguela dentistry course, Benguela Province, Angola

Benguela is Angola's third most populated province with 2,600,000 inhabitants. The municipality of the same name is the second most populous within the province with 747,000 inhabitants. There is in Benguela province ten municipalities, of which four are located along the coast, with a population of over 2,000,000. The most populous municipality is called Lobito, with 842,952 inhabitants.

With one public university and five Private Superior Institutes in the municipalities of Benguela and Lobito, Benguela Higher Polytechnic Institute is a private HEI located at the city center. A more detailed analysis of the Polytechnic Higher Institute of Benguela, was performed, where data were obtained from the academic services department as shown in the table 3. The curriculum consists of twenty-four annual and twenty-one semester subjects. The workload spans 5,370 h over six years of training and the student begins to attend clinics in the fifth semester. On an average, twenty-five students complete the course annually. It has one dental laboratory that services the central and southern region of the country and dental clinics.

Table 3. Dentistry study plan of the Polytechnic Higher Institute of Benguela.

\begin{tabular}{|c|c|c|c|c|c|}
\hline Course unit & Workload & $\begin{array}{l}\text { Annual (A) and } \\
\text { Semiannual (S) }\end{array}$ & Course unit & Workload & $\begin{array}{l}\text { Annual (A) and } \\
\text { Semiannual (S) }\end{array}$ \\
\hline \multicolumn{6}{|c|}{$1^{\text {st }}$ Year } \\
\hline \multicolumn{3}{|c|}{ 1st Semester } & \multicolumn{3}{|c|}{ 2nd Semester } \\
\hline Biostatistics and Informatics & 60 & $\mathrm{~A}$ & Biostatistics and Informatics & 60 & $\mathrm{~A}$ \\
\hline Cellular and Molecular Biology & 120 & A & Cellular and molecular biology & 120 & A \\
\hline Biochemistry & 120 & A & Biochemistry & 120 & A \\
\hline Human Physiology & 120 & A & Human Physiology & 120 & A \\
\hline Integrated Human Anatomy I & 75 & $\mathrm{~S}$ & Integrated Human Anatomy II & 75 & S \\
\hline Biophysics & 60 & $\mathrm{~S}$ & Terminology & 45 & S \\
\hline Introduction to the Profession & 30 & $\mathrm{~S}$ & & & \\
\hline
\end{tabular}




\begin{tabular}{|c|c|c|c|c|c|}
\hline \multicolumn{6}{|c|}{$2^{\text {nd }}$ Year } \\
\hline \multicolumn{3}{|c|}{ 3rd Semester } & \multicolumn{3}{|c|}{ 4th Semester } \\
\hline Pharmacology & 105 & A & Pharmacology & 105 & A \\
\hline Medical Microbiology & 120 & A & Medical Microbiology & 120 & A \\
\hline Oral Morphology & 120 & A & Oral Morphology & 120 & A \\
\hline Integrated Human Anatomy III & 75 & $\mathrm{~S}$ & Head and Neck Anatomy & 75 & $\mathrm{~S}$ \\
\hline Biopathology & 45 & $\mathrm{~S}$ & Immunology & 60 & $\mathrm{~S}$ \\
\hline Genetics & 60 & $S$ & Dental Materials & 60 & $S$ \\
\hline \multicolumn{6}{|c|}{$3^{\text {rd }}$ Year } \\
\hline \multicolumn{3}{|c|}{ 5th Semester } & \multicolumn{3}{|c|}{ 6th Semester } \\
\hline Imaging & 75 & A & Imaging & 75 & A \\
\hline $\begin{array}{l}\text { Preventive and Community } \\
\text { Dentistry }\end{array}$ & 75 & A & $\begin{array}{l}\text { Preventive and Community } \\
\text { Dentistry }\end{array}$ & 75 & A \\
\hline Dentistry Techniques & 75 & A & Dentistry Techniques & 75 & A \\
\hline Endodontic Techniques & 120 & A & Endodontic Techniques & 120 & A \\
\hline Pharmacological Therapy & 30 & A & Pharmacological Therapy & 30 & A \\
\hline Pathologic Anatomy & 75 & $\mathrm{~S}$ & Periodontology & 45 & $\mathrm{~S}$ \\
\hline Pediatric Dentistry & 45 & $\mathrm{~S}$ & Fixed Prosthesis & 45 & $\mathrm{~S}$ \\
\hline $\begin{array}{l}\text { Propaedeutic and Medical } \\
\text { Pathology }\end{array}$ & 60 & $S$ & Removable Prosthesis & 60 & $\mathrm{~S}$ \\
\hline $\begin{array}{l}\text { Oral Anesthesia and Surgery } \\
\text { Techniques }\end{array}$ & 45 & $S$ & Psychology & 60 & $\mathrm{~S}$ \\
\hline
\end{tabular}

\begin{tabular}{|c|c|c|c|c|c|}
\hline \multicolumn{6}{|c|}{$4^{\text {th }}$ Year } \\
\hline \multicolumn{3}{|c|}{ 7th Semester } & \multicolumn{3}{|c|}{ 8th Semester } \\
\hline $\begin{array}{l}\text { Surgical and Periodontal Clinic } \\
\text { I }\end{array}$ & 210 & A & $\begin{array}{l}\text { Surgical and Periodontal Clinic } \\
\text { I }\end{array}$ & 210 & A \\
\hline Oral Rehabilitation Clinic I & 270 & A & Oral Rehabilitation Clinic I & 270 & A \\
\hline Pediatric Dentistry Clinic I & 210 & A & Pediatric Dentistry Clinic I & 210 & A \\
\hline $\begin{array}{l}\text { Restorative and Conservative } \\
\text { Clinic I }\end{array}$ & 240 & A & $\begin{array}{l}\text { Restorative and Conservative } \\
\text { Clinic I }\end{array}$ & 240 & A \\
\hline
\end{tabular}

$5^{\text {th }}$ Year

9th Semester

10th Semester

\begin{tabular}{|c|c|c|c|c|}
\hline $\begin{array}{l}\text { Surgical and Periodontal Clinic } \\
\text { II }\end{array}$ & 120 & A & $\begin{array}{l}\text { Surgical and Periodontal Clinic } \\
\text { II }\end{array}$ & 120 \\
\hline $\begin{array}{l}\text { Special and Dental Patients } \\
\text { Clinic }\end{array}$ & 60 & A & $\begin{array}{l}\text { Special and Dental Patients } \\
\text { Clinic }\end{array}$ & 60 \\
\hline Oral Rehabilitation Clinic II & 240 & A & Oral Rehabilitation Clinic II & 240 \\
\hline Pediatric Dentistry Clinic II & 180 & A & Pediatric Dentistry Clinic II & 180 \\
\hline $\begin{array}{l}\text { Restorative and Conservative } \\
\text { Clinic II }\end{array}$ & 240 & A & $\begin{array}{l}\text { Restorative and Conservative } \\
\text { Clinic II }\end{array}$ & 240 \\
\hline
\end{tabular}


Ethics, Deontology and

Professional Legislation

15

$S$

Forensic Dentistry

60

$6^{\text {th }}$ Year

11th Semester

12 th Semester

\begin{tabular}{llllll}
\hline Health Center Internship & 240 & A & Health Center Internship & 240 & A \\
Dental Clinic Internship & 720 & A & Dental Clinic Internship & 720 & A \\
Hospital internship & 330 & A & Hospital internship & 330 & A \\
\hline
\end{tabular}

Source: Authors.

\section{Discussion}

The delay in the development of courses for higher education in Angola and the time gap between the conception of new dentistry courses in 2008 and their realization can be attributed to the history of colonization and civil war, and changes resulting from the nationalization of education in the post-independence period (Aguiar \& Moreno, 2017). This study highlighted the condition of HEIs for dentistry in Angola and the extreme scarcity of human resources. The country offers only eight dentistry courses, although ten are legalized.

There are no fixed parameters, globally recommended, on the ideal proportion of inhabitants per dentist, as this demand may vary according to the needs of the population, considering the diversity of local, socioeconomic, cultural and epidemiological factors, among others, which differ from country to country, so that a greater degree of vulnerability of the population requires a greater number of available professionals. Comparatively, in India a ratio of 1/7,500 is recommended, while in Brazil, the recommendation of the Ministry of Health of Brazil for dentists working in primary care is one dentist for every 3,000 inhabitants, on average (Yadav \& Rawal, 2016; Cascaes et al., 2018). This suggests that the population of Angola faces a severe deficiency in the availability of human resources aimed at assisting the population's oral health.

Most HEIs in Angola do not provide the curriculum and other data that would facilitate a thorough and detailed analysis of academic projects in their databases and official pages, and two do not provide any information. It is considered important to have information about academic projects on the official pages and to be linked to social media, as they can increase the number of visits to these higher education institutions and, nowadays, the worldwide computer network allows the dissemination of information in a timely manner real. A study demonstrated that the use of social media among students and candidates for the dentistry course has a positive impact for the dissemination of the profession and the projection of educational institutions, showing that social media is part of the current world, of which the health area does not. is excluded (Oakley \& Spallek, 2012).

Students should be in the incessant pursuit of knowledge in order to pursue continuing education (Moimaz et al., 2016). However in Angola, this reality is considered difficult since the training is only done in private schools and often the cost of living has prevented the population from taking the course with the conditions placed at the disposal of the population to obtain an undergraduate degree in dentistry, in a period ranging from 4 to 6 years of training, depending on the school. It is clear that there is a similarity in the workload of the entire course that varies, between 4,688 hours and 5,536 hours, which is similar to the workload applied at some Brazilian universities, as well as the São Paulo State University (UNESP) and the University of São Paulo (USP), which is 4,830 hours and 5,400 hours respectively (Universidade Estadual Paulista-UNESP, 2018; Universidade de São Paulo-USP, 2019).

For many applicants, the offer of a private HEI dentistry course and the cost can be a barrier, considering that the minimum wage in Angola is US\$ 40 and the cost of a monthly tuition is twice the minimum wage (about US\$ 85). In order to minimize the financial need to have access to a dentistry course in Angola, there would be a need to focus on distance 
education, thereby ensuring partnership and support from HEIs that have already made significant progress in dental education projects and that enable the transmission of knowledge in a way that is less costly and comprehensive to even the most needy. Candidates are subjected to an aptitude test. Enter to an HEI in Angola requires a minimum grade of 10 values on a scale of 020. The maximum age of selection in public medical schools is 30 years. People under the age of 30 cannot apply for the position, so those who would like to study medicine above the permitted age end up taking the dentistry course. This condition further increases the demand for the course for people over 30 years old.

There is concern that the linked value of dental education and research will be compromised when schools move away from research-intensive institutions and academic health centers (Kassebaum \& Tedesco, 2017). That's why, the President of the Republic of Angola approved the Career Statute of the Scientific Researcher, to mitigate the shortage of researchers in the country. The approved decree provides incentives for researchers. As it is recent, it is thought that it will facilitate motivation and encouragement from the government and provide the necessary support to strengthen higher education, by increasing the number of HEIs offering undergraduate dentistry courses and the commencement of postgraduate dentistry courses.

In the teaching of dentistry, the focus has always privileged the treatment of diseases based on the most recent technological arsenal. The curriculum of Dentistry courses has always privileged the curative paradigm, which is the guiding philosophy of universities, whose teaching is not guided by the epidemiological, social, cultural and economic situation of the population (Garbin et al., 2005). The curricula of the schools analyzed favor a greater number of practical laboratory disciplines in relation to the workload attributed to learning curative activities with patient care.

Currently, the teacher as a simple content distributor has the days numbered, because the market today requires a teacher to share their knowledge with students and even learn from them, as new knowledge is emerging every day and many Sometimes the teacher doesn't even know the facts. Thus, the teacher should change the focus of teaching to reproduce knowledge and start to worry about learning and, in particular, "learning to learn", opening collective paths in search and investigation for the production of his own knowledge and knowledge your student (Rodrigues, Saliba, \& Moimaz, 2006).

Curriculum plans were collected from schools with some difficulty, owing to the bureaucracy that dominates the country and also extends to HEIs. Thus, only six HEI curricula were available and only three included the course load. The standardization and availability of dentistry courses in Angola will require a considerable amount of time, given the existence of bureaucratic barriers at administrative levels in HEIs. It was impossible to estimate the number of students enrolling in dentistry courses annually and the number of teachers in undergraduate dentistry courses, owing to lack of data on the official pages of the HEIs. Despite the sending of e-mails to the contacts listed on the official page of the HEIs, and attempts to directly contact the corresponding areas of the HEIs, no responses were received. The difficulty that HEIs have in providing the exact number of teachers is justified by the fact that the few teachers available to work in more than one HEI.

It is important to emphasize here that, as the teaching of dentistry that is still considered embryonic in Angola, it should be mentioned that it does not yet have a community, association or institution that is exclusively responsible for taking care of policies aimed at teaching dentistry. All policies adopted by the government are widespread, it is necessary to create an independent institution, which takes care and monitors the development of dental education policies in the country as it happens in other realities, to set goals and provide the growth, not only of the academic curriculum, but also of the professionals who work in the area. By way of example, ADEA already has a 2019-2022 access, diversity and inclusion strategic framework (American Dental Education Association, 2019). In Angola, due to the lack of an institution that regulates the teaching of dentistry, the goals and strategies end up being idealized mainly in the HEI, hindering the growth of the area, in general.

Urging the need for curriculum change, a study on the case of change in dental education in the United States characterized dental education curricula as overcrowded, uncontrollable, inflexible, disjointed, irrelevant, and without effective 
connectivity among basic science, behavioral science, and clinical science. Further, the system is permeated by a culture that supports the memorization of factual knowledge over reasoning based on evidence and critical thinking skills (Pyle et al., 2006). For meaningful curriculum change to occur in dental schools, faculty must go through a process of new skills development that will prepare them to teach differently and to assess students differently than they have before. Curriculum change and the faculty development process must have the support of the dental school's leadership and become a core value of the school's culture (Licari, 2007).

The study had limitations related to the reduced number of HEIs that make their curricular plans available on their official pages. Bureaucracy for the acquisition of curricular plans was also one of the limiting factors.

The dissemination of information regarding the ground reality and scarcity of undergraduate courses requires the attention of international authorities, so that local authorities can be encouraged to create intervention policies aimed at increasing dentistry courses in public HEIs and to focus on improving human resources in response to the oral health needs of the population.

\section{Conclusion}

It was concluded that of the total of seven academic regions in the country, four do not have courses in dentistry; the proportion of inhabitants of Angola to the number of dentists in the country is high; no HEI offered postgraduate courses in dentistry and there is no standardization of pedagogical projects among the existing undergraduate courses. New studies should be carried out to encourage the planning, creation, development and evaluation of policies and strategies aimed at expanding the training of human resources in the dental field, aiming to respond the oral health needs of the population of Angola.

\section{Acknowledgments}

This study was financed in part by the Coordenação de Aperfeiçoamento de Pessoal de Nível Superior - Brasil (CAPES) - Finance Code 001.

\section{References}

Aguiar, A. S. W., \& Moreno, M. S. (2017). Cursos de Odontologia/Medicina dentária nos países africanos de língua oficial portuguesa. Jornal Acadêmico de Atualizações Médicas, 1, 17-24.

American Dental Education Association. (2019). ADEA Strategic Framework, 2019-22. Journal of dental education, 83, 763-764.

Carvalho, P. (2012). Evolução e crescimento do ensino superior em Angola. Revista Angolana de Sociologia, 9, 51-58.

Cascaes, A. M., Dotto, L., \& Bomfim, R. A. (2018). Tendências da força de trabalho de cirurgiões-dentistas no Brasil, no período de 2007 a 2014: estudo de séries temporais com dados do Cadastro Nacional de Estabelecimentos de Saúde. Epidemiologia e Serviços de Saúde, 27(1), e201723615. https://doi.org/10.5123/s1679-49742018000100015

Dussault, G., Fronteira, I., \& World Health Organization. (2010). Análise dos recursos humanos da saúde (RHS) nos países africanos de língua oficial portuguesa (PALOP). Geneva: World Health Organization.

Garbin, C. A. S., Saliba, N. A., Moimaz, S. A. S., \& Santos, K. T. (2005). The role of universities in the training health professionals. Revista da ABENO, 6, 610 .

Governo da República de Angola. (2001). Estratégia integrada para melhoria do sistema de educação: 2001-2015. http://planipolis.iiep.unesco.org/sites/planipolis/files/ressources/angola_estrategia_integrada_melhoria.pdf

Governo da República de Angola. (2008). Diário da República I série n ${ }^{\circ} 155$. Cria na Universidade Privada de Angola os seguintes cursos, que conferem o grau de licenciatura. https://www.imprensanacional.gov.ao/index.php?id=105\&serie=1\&token=f4fedaaf0407 819661189203960f05 36\&de Ano=2 007\&ate $\mathrm{Ano}=2008 \&$ numero $=155$

Governo da República de Angola. (2009). Decreto n. ${ }^{\circ}$ 5/09, de 7 de abril. Cria as Regiões Académicas que delimitam o âmbito territorial de atuação e expansão das instituições de ensino superior. https://welvitchia.com/SESA_files/DR\%20Decreto\%205_09_Cria\%20Regioes \%20Academic as\%20que\% 20Delimitam\%20Ambito\%20Territorial\%20Actuacao\%20e\%20Expansao\%20Inst \%20Ens\%20Sup.pdf 
Research, Society and Development, v. 10, n. 4, e51110414356, 2021

(CC BY 4.0) | ISSN 2525-3409 | DOI: http://dx.doi.org/10.33448/rsd-v10i4.14356

Governo da República de Angola. (2019). Estatuto da carreira de investigador científico. https://www.ciencia.ao/images/legisla cao/Estatuto_da_Carreira_de_Invest_Cientifico109_19_2Abril.pdf

Grossman, E. S., Naidoo, S. (2012). Academic-service partnerships, research, and the South African dental academic. Journal of dental education, 76(9), 1226-1233.

Instituto Nacional de Estatística de Angola. (2019). Estatísticas Sociais. https://www.ine.gov.ao/inicio/estatisticas

Karim, A., Mascarenhas, A. K., Dharamsi, S. (2008). A global oral health course: isn't it time? Journal of dental education, 72(11), $1238-1246$.

Kassebaum, D. K., \& Tedesco, L. A. (2017). The 21st century dental curriculum: a framework for understanding current models. Journal of dental education, 81, eS13-21. https://doi.org/10.21815/JDE.017.002

Liberato, E. (2014). Avanços e retrocessos da educação em Angola. Revista Brasileira de Educação, 19, 1003-1031. https://doi.org/10.1590/S141324782014000900010

Licari, F. W. (2007). Faculty development to support curriculum change and ensure the future vitality of dental education. Journal of dental education, 71 , $1509-1512$

Moimaz, S. A. S., Fadel, C. B., Bino, L. S., \& Saliba, N. A. (2010). Pedagogical project and curricular structure of a dentistry course: critical analysis based on academic perception. Revista da ABENO, 10, 35-40.

Oakley, M., \& Spallek, H. (2012). Social in dental education: a call for research and action. Journal of dental education, 76(3), 279-287.

Parkash, H., Mathur, V. P., Dugal, R., \& Jhuraney, B. (2006). Dental workforce issues: a global concern. Journal of dental education, 70(11 Suppl), $22-26$.

Peters, M. C., Ababiu, F. A., Ananaba, N. P. J., \& Johnson, L. A. (2013). Students clinical learning in an emerging dental school: an investigation in international collaboration between Michigan and Ghana. Journal of dental education, 77(12), 1653-1661.

Pyle, M., Andrieu, S. C., Chadwick, D. G., Chmar, J. E., Cole, J. R., George, M. C., Glickman, G. N., Glover, J. F., Goldberg, J. S., Haden, N. K., Hendricson, W. D., Meyerowitz, C., Neumann, L., Tedesco, L. A., Valachovic, R. W., Weaver, R. G., Winder, R. L., Young, S. K., Kalkwarf, K. L., \& ADEA Commission on change and innovation in dental education. (2006). The case for change in dental education. Journal of Dental Education, 70, 921-924.

Rodrigues, R. P. C. B., Saliba, N. A., \& Moimaz, S. A. S. (2006). Public Health Dentistry in the curricular structure of dental courses in Brazil. Revista da ABENO, 6, 81-87. https://doi.org/10.30979/rev.abeno.v6i1.1453

Thorpe S. (2006). Oral health issues in the african region: current situation and future perspectives. Journal of dental education, 70(11 Suppl), 8-15. https://doi.org/10.1002/j.0022-0337.2006.70.11_suppl.tb04209.x

Universidade de São Paulo - USP. (2019). Grade curricular. Faculdade de Odontologia. https://uspdigital.usp.br/jupiterweb/listarGradeCur ricular? codcg= $23 \&$ codcur $=23011 \&$ codhab $=0 \&$ tipo $=\mathrm{N}$

Universidade Estadual Paulista - UNESP. (2018). Estrutura curricular: odontologia. www.ict.unesp.br/\#!/ensino/graduacao/odontologia/estrutura-curricular/.

Yadav, S., \& Rawal, G. (2016). The current status of dental graduates in India. The Pan African medical journal, $23,22$. https://doi.org/10.11604/pamj.2016.23.22.7381 